\title{
Late Pleistocene and Holocene environmental evolution of the Wkra River Valley near Bielawy Gołuskie (central Poland) recorded in palaeo-oxbow lake deposits
}

\author{
Monika NISKA ${ }^{1, *}$, Jerzy JONCZAK² and Joanna GADZISZEWSKA ${ }^{1}$ \\ 1 Pomeranian University in Słupsk, Institute of Geography and Regional Studies, Partyzantów 27, 76-200 Słupsk, Poland \\ 2 Warsaw University of Life Sciences, Department of Soil Environment Sciences, Nowoursynowska 159, 02-776 Warszawa, \\ Poland
}

Niska, M., Jonczak, J., Gadziszewska, J., 2017. Late Pleistocene and Holocene environmental evolution of the Wkra River Valley near Bielawy Gołuskie (central Poland) recorded in palaeo-oxbow lake deposits. Geological Quarterly, 61 (2): 305-318, doi: 10.7306/gq.1320

\begin{abstract}
This study aimed to reconstruct environmental changes in the Wkra River Valley near Bielawy Gołuskie (central Poland) based on geochemical, palynological and subfossil Cladocera analysis of deposits filling a palaeo-oxbow lake. Two sediment boreholes collected from the palaeochannel bend (BG-1) and neck (BG-2) include full sequences of organic deposits lying on clastic deposits. The lower part of the BG-1 borehole contains gyttja that accumulated during the Younger Dryas and the Preboreal, which is covered by reed peat of Preboreal and Boreal age. On top of this is alder peat that accumulated during the Atlantic. The ages of the gyttja and peat were confirmed by both radiocarbon dating and palynological analysis. The peats are characterized by a significant content of organic matter, which is relatively stable over time. This indicates a low intensity of mechanical denudation in the catchment, which is supported by low concentrations of aluminum and potassium. Calcium values greatly exceed these elements, suggesting that the lake was mainly fed by groundwater. Variation in trophic conditions over time is indicated by a vertical variability in the content of nitrogen, as well as by the Cladocera population. The strong decomposition of peat in the top layer of the mire, and increased concentrations of phosphorus and heavy metals, testify to increasing human activity during the most recent time periods.
\end{abstract}

Key words: oxbow lake, Wkra River, Poland, Multi-proxy analysis, Early Holocene.

\section{INTRODUCTION}

The development of lakes, constituting important postglacial landscape elements (Kalinowska, 1961), is strongly associated with a basal fill of stratified deposits that are characterized by variable physico-chemical properties over time. The accumulation results in filling and finally terrestrialization of the reservoir. The intensity of this process and the nature of the sediments are affected by many environmental factors, including e.g. climatic conditions, intensity of mechanical and chemical denudation in the catchment, its cover, species composition and frequency of lake organisms (Marszelewski et al., 2011). In this way, lake deposits constitute archives of past environments of the reservoir and its catchment that can be reconstructed by palaeoecological studies.

Geochemical analysis of sediments is important for palaeoenvironmental reconstructions, especially the investigation of $\mathrm{pH}$ and the content of basic components including silica, carbonates, organic matter and some elements, particularly $\mathrm{C}$,

\footnotetext{
* Corresponding author, e-mail: monikaniska@wp.pl

Received: January 1, 2016; accepted: April 26, 2016; first published online: January 31, 2017
}

$\mathrm{N}, \mathrm{P}, \mathrm{K}, \mathrm{Ca}, \mathrm{Mg}, \mathrm{Fe}, \mathrm{Al}, \mathrm{Mn}, \mathrm{Cu}, \mathrm{Zn}, \mathrm{Ni}$ and Pb (Wojciechowski, 2000; Borówka, 2007). Furthermore, valuable analyses include speciation of elements, the content of their isotopes, or qualitative and quantitative analysis of specific organic and inorganic compounds (Herczeg, 1988; Martinova, 1993; Meyers and Lallier-Vergčs, 1999; Enders and Pagani, 2008). In many studies, the interactions between physico-chemical parameters of the sediments and environmental conditions in the lakes and their catchments have been identified. For example, the contents of silica, potassium and aluminum are commonly considered as indicators of mechanical denudation intensity, whereas the content of calcium reflects the intensity of chemical denudation. The abundance of nitrogen and phosphorus provides information about trophic conditions; concentrations of heavy metals are indices of human activity (Hamilton-Taylor, 1979; Abraham, 1998; Last and Smol, 2001; Rose et al., 2004; Jin et al., 2006; Borówka, 2007; Schmidt et al., 2008; Pawłowski et al., $2015 a$, b). However, primary features of sediments can undergo transformation in post-sedimentation processes (Boyle, 2001; Haggard et al., 2005; Wilson et al., 2008), which may hamper correct interpretation.

Integrating the results of geochemical analysis and the composition and frequency of various microorganisms preserved in sediments provides a much more complete picture of past environments (Galbarczyk-Gąsiorowska et al., 2009; Pawłowski et al., 2015a, b). Pollen analysis, especially when 
combined with radiocarbon dates, plays a key role in reconstructing the past vegetation of the palaeo-lakes, allowing the establishment of a chronology of the deposits (Latałowa, 1982; Latałowa and Tobolski, 1989). Past ecological conditions of the basin can furthermore be reconstructed from malacological analyses (Wojciechowski, 1987, 2000) and Cladocera analysis (Mirosław-Grabowska and Niska, 2005; Mirosław-Grabowska et al., 2009; Niska, 2013). The value of these groups of organisms is related to the fact that many species are adapted to narrow environmental ranges. Cladocera, which are the major constituents of lake zooplankton, inhabit mostly stagnant lakes (Kajak, 2001), particularly under conditions of a stable lake level (Lampert and Sommer, 2001), including oxbow lakes (Dembowska and Napiórkowski, 2012). However, environmental reconstructions of palaeo-oxbow lake deposits may be difficult due to the significant dynamics of river valley geosystems and fluvial processes, which can disrupt sedimentation, leading to the formation of stratigraphic hiatuses (Pawłowski et al., 2015a).

Our study aims to bring new information on past environments in the Wkra River Valley near Bielawy Gołuskie (central Poland) based on the analysis of geochemistry, pollen and subfossil Cladocera of palaeo-oxbow lake deposits. The recon- struction includes the chronology of oxbow lake formation and its cut-off from the river, the temporal variability of trophic conditions in the lake, the intensity of mechanical and chemical denudation in the catchment, the succession of vegetation and Cladocera, and the identification of human activities against the background of past climate changes.

\section{MATERIALS AND METHODS}

\section{STUDY AREA}

The studies were carried out in a palaeo-oxbow lake on the east side of the Wkra River Valley near the village of Bielawy Gołuskie (52 ${ }^{\circ} 93.7270^{\prime}$ N, $19^{\circ} 96.6163^{\prime}$ E; Fig. 1). The area is located at the margins of the Raciąska Plain (Kondracki, 2000), which is a glaciofluvial plateau that developed during the maximum expansion of the Vistula Glaciation, lying at the elevations of 113-121 $\mathrm{m}$ a.s.I. The glaciofluvial landscape contains outcrops of older glacial tills that are locally covered by coarse-grained residual materials with stones and boulders, Late Pleistocene and Holocene dunes, and kettle holes of variable
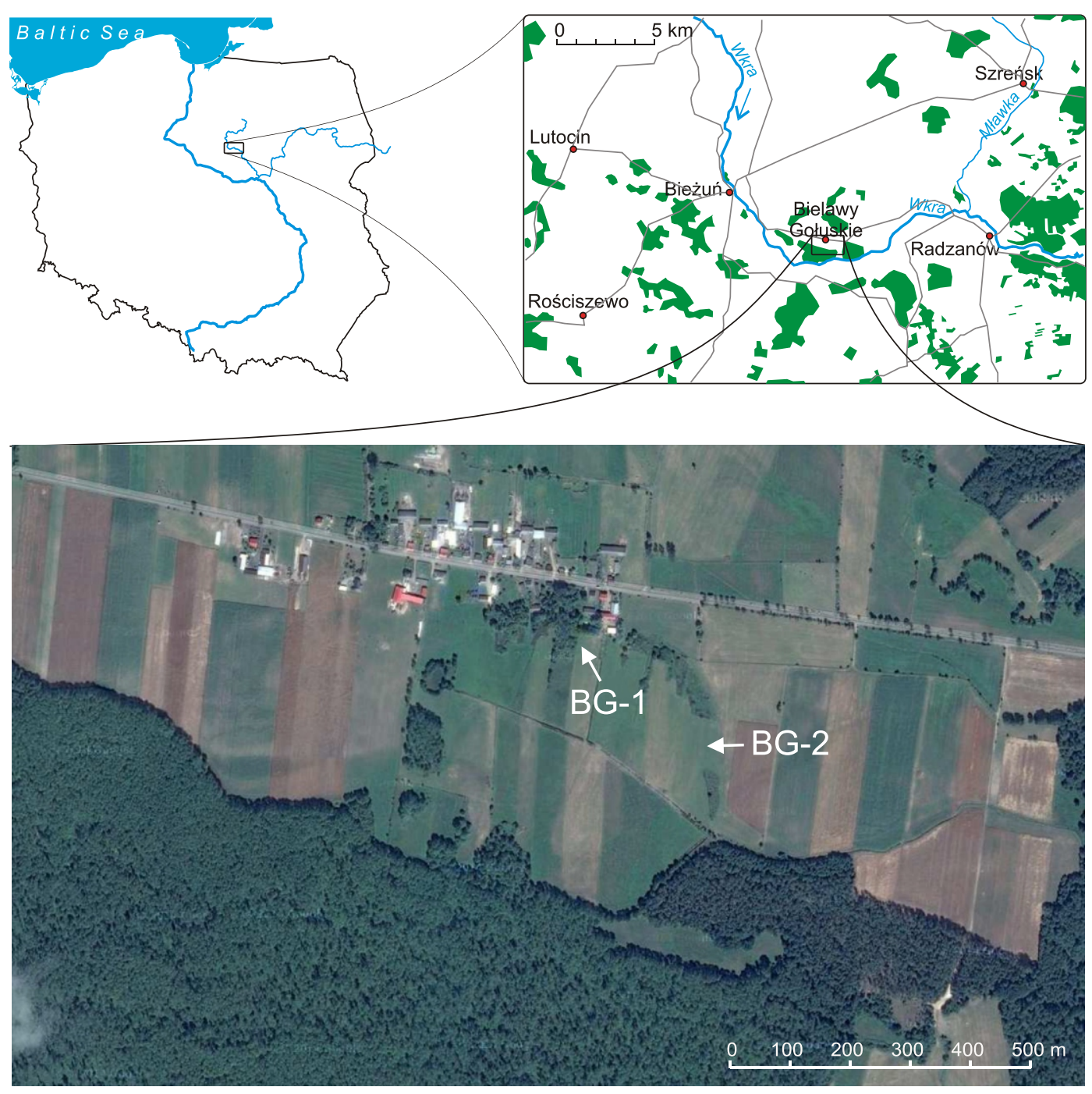

Fig. 1. Location of study site and boreholes within the palaeo-oxbow lake 
sizes that are filled with peat and gyttja (Kotarbiński, 2003). This landscape is cut by the $\sim 1 \mathrm{~km}$ wide Wkra River valley. The bottom of the valley is filled with alluvial deposits with thicknesses of up to $\sim 4 \mathrm{~m}$. Many palaeochannels in the valley constitute evidence of the past activity of a meandering river. The age and stage of the palaeochannels are variable. The oldest are probably the large palaeo-oxbow lakes along the valley margins that at present are completely or almost completely filled with organic deposits. Drainage works within the valley bottom and straightening of the river channel during the mid-20th century decreased the groundwater level and led to the disappearance of some water bodies.

\section{SAMPLING}

Two sediment boreholes with a length of $2 \mathrm{~m}$ were taken from the palaeo-oxbow lake bend (BG-1) and neck (BG-2) (Fig. 1) using a $75 \mathrm{~mm}$ Instorf corer, covering the complete lake fill and the upper layers of the underlying clastic deposits. Samples were taken for geochemical analyses $(5 \mathrm{~cm}$ sample interval), palynological studies (sample interval $8 \mathrm{~cm}$ ), Cladocera analysis ( $8 \mathrm{~cm}$ sample interval) and radiocarbon analysis (selected levels).

\section{RADIOCARBON DATING}

Radiocarbon dates were obtained from plant remains collected at three depths in borehole BG-1. Dating was performed in the Laboratory of Absolute Dating in Cianowice. Conventional dates were calibrated using OxCal 4.2.3 software (Bronk Ramsey, 2013) and the IntCal13 calibration curve (Reimer et al., 2013). Here, dates are given in calibrated years BP.

\section{POLLEN ANALYSIS}

Samples of $1 \mathrm{~cm}^{3}$ volume were boiled in $10 \% \mathrm{KOH}$, treated with $10 \% \mathrm{HCl}$ or soaked for several days in $\mathrm{HF}$ (depending on the sediment composition) and then acetolysed (Faegri and
Iversen, 1989; Dybova-Jachowicz and Sadowska, 2003). As a rule, in each sample 700 pollen grains of tree and shrub pollen (AP) and all accompanying pollen of herbs (NAP) and spores of Pteridophytes and mosses were determined and counted. Calculations were based on AP + NAP $=100 \%$; pollen and spores of aquatic and wetland species are excluded from the calculation sum. Also, microremains of algae, Cyanobacteria, fungi and some fauna (non-pollen palynomorphs - NPPs) were counted (Van Geel, 2001; Jankovská and Komárek, 2001). The results of pollen analysis (Figs. 2 and 3 ) are displayed using the PolPal software (Nalepka and Walanus, 2003).

\section{GEOCHEMICAL ANALYSIS}

Samples were dried at $65^{\circ} \mathrm{C}$, pulverised with an analytical mill with a tungsten blade (organic samples) or agate mortar (mineral samples) and stored in closed polyethylene bags. The analysis included:

- determination of $\mathrm{pH}$ potentiometrically in suspension with water (1:10);

- determination of carbonate content with the volumetric Scheibler's method;

- determination of organic matter content (OM) as losson-ignition at $550^{\circ} \mathrm{C}$;

- determination of total organic carbon (TO) content with the method of Alten et al. (1935);

- determination of total nitrogen $(\mathrm{N})$ content with Kjeldahl's method (Page, 1982);

- determination of the content of $\mathrm{P}, \mathrm{Na}, \mathrm{K}, \mathrm{Ca}, \mathrm{Mg}, \mathrm{Fe}, \mathrm{Al}$, $\mathrm{Mn}, \mathrm{Cu}$ and $\mathrm{Zn}$ after sample digestion in a mixture of $65 \% \mathrm{HNO}_{3}, 60 \% \mathrm{HClO}_{4}$ and concentrated $\mathrm{H}_{2} \mathrm{SO}_{4}$ in the proportion 20:5:1 by volume. The concentration of $\mathrm{P}$ in solutions was analysed colorimetrically by the molybdenum blue method, and the remaining elements by microwave plasma atomic emission spectrometry (Agilent 4100 MP-AES).

Based on the chemistry of borehole BG-1, five geochemical zones were identified using cluster analysis with PAST 3.10 software (Fig. 4; Hammer et al., 2001).

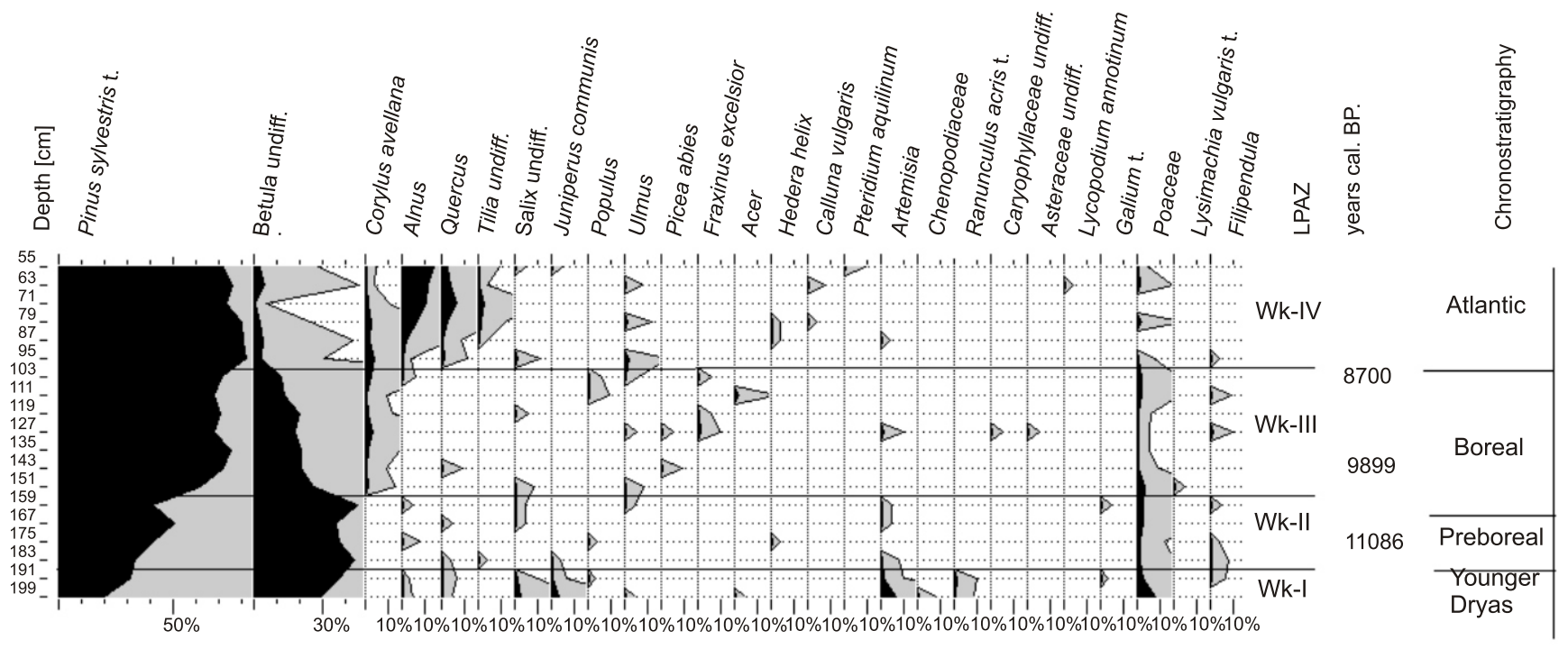

Fig. 2. Percentage pollen diagram of borehole BG-1 


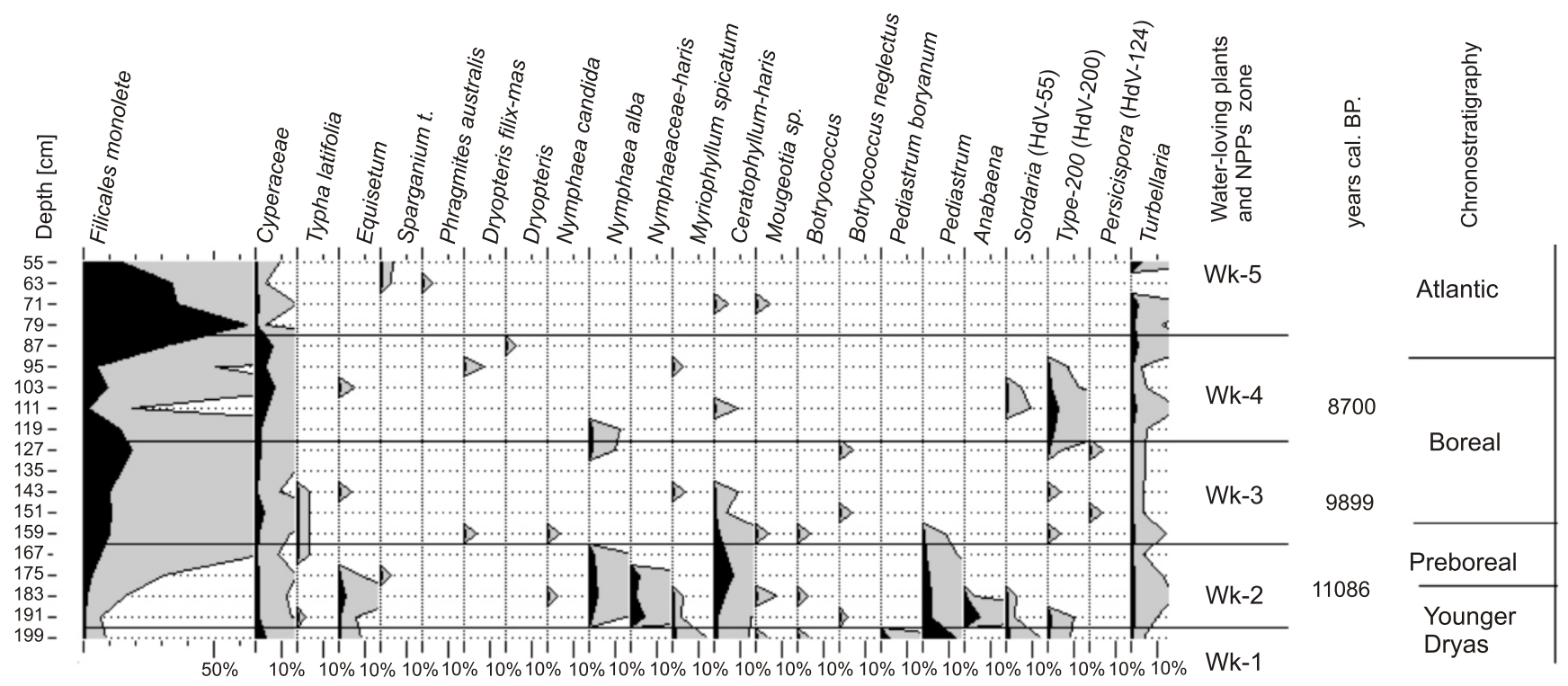

Fig. 3. Percentage diagram of non-pollen palynomorphs (NPPs) and pollen of aquatic and marsh plants of borehole BG-1

\section{CLADOCERA ANALYSIS}

Samples with a volume of $1 \mathrm{~cm}^{3}$ were prepared using a slightly modified standard procedure (Frey, 1986; Korhola and Rautio, 2001). After removal of carbonates using $10 \% \mathrm{HCl}$, each sample was boiled in $10 \% \mathrm{KOH}$ for 20 minutes, washed with distilled water and sieved through a $40 \mu \mathrm{m}$ mesh sieve. The fine material was transferred into a polycarbon test tube. Prior to counting, the remains were coloured with safranine $T$. The analysis was performed with a Nikon model ECLIPSE Ci-L microscope with magnifications of $x 10, x 40$ and $x 60$. A minimum of 200 remains of Cladocera (3-8 slides) were examined in each sample. First, all remains from each slide were counted (headshields, shells, postabdomens, postabdominal claws and antennules) and then converted to one Cladocera specimen and all ephippia together.

Identification and ecological interpretation of the Cladocera remains were based on Frey (1958, 1962), Goulden (1964), Szeroczyńska (1985, 1998), Hofmann (1986, 2000), Korhola (1990), Duigan (1992), Flössner (2000) and Szeroczyńska and Sarmaja-Korjonen (2007). The results of Cladocera analyses are shown in Figures 5 and 6 , and include the percentage diagram, the total number of Cladocera individuals, and number of species including their biodiversity. The numerical analysis was performed with the PolPal computer program (Nalepka and Walanus, 2003).

The Cladocera species were classified into four habitat preference groups: bottom-dweller species, species associated with/restricted to vegetation and planktonic (offshore) and littoral (meiobenthic) groups (Flössner, 1964; Whiteside, 1970; Whiteside and Swindoll, 1988; Korhola, 1990).

\section{RESULTS}

\section{LITHOLOGY AND AGE OF DEPOSITS}

The radiocarbon dates show that the sediments were deposited between the Younger Dryas and the Atlantic period. Unfortu- nately we were not able to date the disappearance of the lake precisely. Organic sediments overlie coarse-grained river sands in borehole BG-1 and gyttja in borehole BG-2. Borehole BG-1 displays a sequence of detritus gyttja $(170-195 \mathrm{~cm})$ that sharply transforms into reed peat $(90-170 \mathrm{~cm})$, which is covered by alder peat $(0-80 \mathrm{~cm})$ (Fig. 2). The radiocarbon age of the central part of the gyttja layer is 11,086 cal. years BP (Table 1). We assume that the gyttja at the bottom of borehole BG-2 $(165-200 \mathrm{~cm})$ is of the same age as the gyttja in borehole BG-1. On top of these deposits, there is a layer of reed peat $(165-115 \mathrm{~cm})$ with a gradual transition to alder peat $(0-80 \mathrm{~cm})$. Between $115-80 \mathrm{~cm}$ there is a gradual transition between reed peat and alder peat. The top layer of peat is strongly decomposed, most likely resulting from mire drainage in the 20th century.

\section{POLLEN ANALYSIS}

In total 25 pollen samples were analysed in borehole BG-1 (Fig. 3). Analyses were not carried out for the top part of the borehole, because of the strong decomposition of the peat. Four pollen zones were identified by visual inspection, based on percentages of pollen attributable to the most important tree and herbaceous plant species (Table 2 and Fig. 2).

\section{SUCCESSION OF TERRESTRIAL VEGETATION}

Wk-I (Artemisia-Poaceae-Juniperus - LPAZ; Late Glacial, $199-187 \mathrm{~cm}$ ). At the close of Late Glacial times, the oxbow lake was surrounded by birch forests with an admixture of pine. There were also shrubs of juniper (Juniperus) and willow (Salix). The presence of open areas within the dry landscape is reflected by a considerable portion of pollen of herbaceous plants, including Artemisia, and representatives of the Chenopodiaceae and Poaceae. In the local vegetation of oxbow lakes Ranunculus acris-t was present.

Wk-II (Betula-Pinus - LPAZ; Preboreal, 187-155 cm). A clear regression of Juniperus communis, Poaceae, and Artemisia indicates the Preboreal period. Climate warming at the be- 


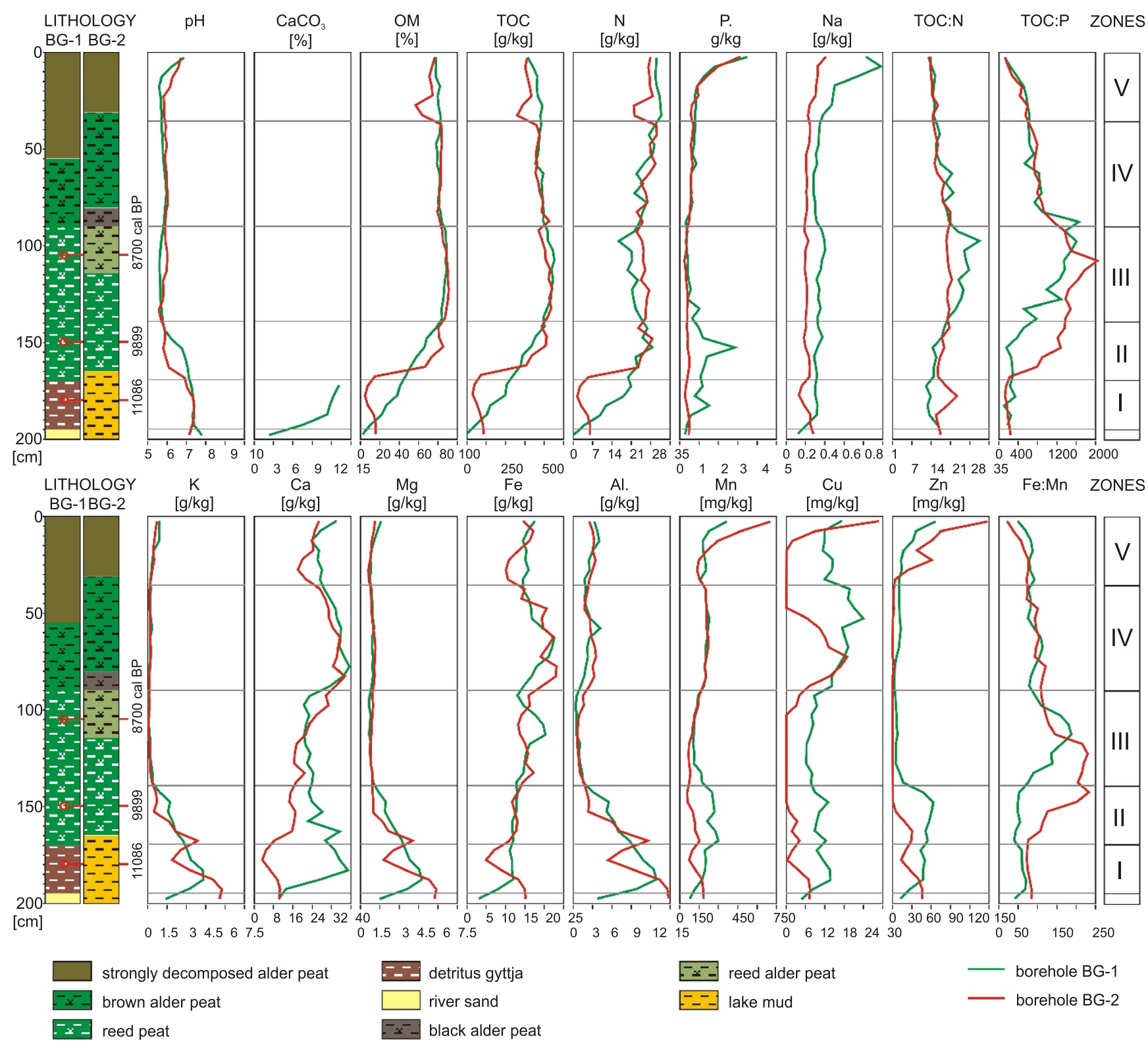

Fig. 4. Lithology, radiocarbon age and chemical composition of sediments in BG-1 and BG-2 boreholes and geochemical zones distinguished based on the chemistry of the borehole

ginning of Holocene times resulted in rapid development of birch forests with admixtures of willow, and subsequently communities with a predominance of pine. Open areas were covered by grass. Another sign of climate warming, among others, is Hedera helix.

Wk-III (Corylus-Pinus - LPAZ; Boreal, 155-99 cm). At approximately $9899 \mathrm{cal}$. BP, forests were dominated by pine, which gradually displaced birch. Within the area studied hazel (Corylus) appeared, which preferred forest outskirts and more humid habitats (Fig. 2). Elm (Ulmus) and ash (Fraxinus) appeared. In some places in the wetlands Filipendula ulmaria was present.

Wk-IV (Pinus-Alnus-Quercus - LPAZ; Atlantic, 99-55 cm). During the Atlantic period, we can see an increasing role of Pinus (Fig. 2). About 8700 cal. BP, in the upper part of the zone, a record of the dynamic expansion of alder (Alnus) is also recorded. In the forest, new tree species (Tilia, Fraxinus, Quercus) are noted.

\section{MICROSCOPIC REMAINS \\ OF AQUATIC AND MARSH}

Based on pollen analysis of aquatic and mire vegetation and other microfossils (NPP - Non-Pollen Palynomorphs; Table 3 and Fig. 3) we distinguished five zones illustrating the evolution of the aquatic-mire ecosystem studied.

Wk-1 (199-195 cm, Late Glacial). Open water favoured the development of planktonic organisms. Among the algae these were species of the genus Pediastrum. In waters macrophytes occurred: Ceratophyllum sp., Nympheae alba and Myriophyllum spicatum. Around the lake rushes predominated with representatives of the Cyperaceae family;

Wk-2 (195-163 cm, Preboreal). At approximately 11086 cal. BP, the water level in the oxbow lake studied became lower, which is reflected in the higher frequency of Filicales monolete spores, Typha latifolia pollen and an expan- 


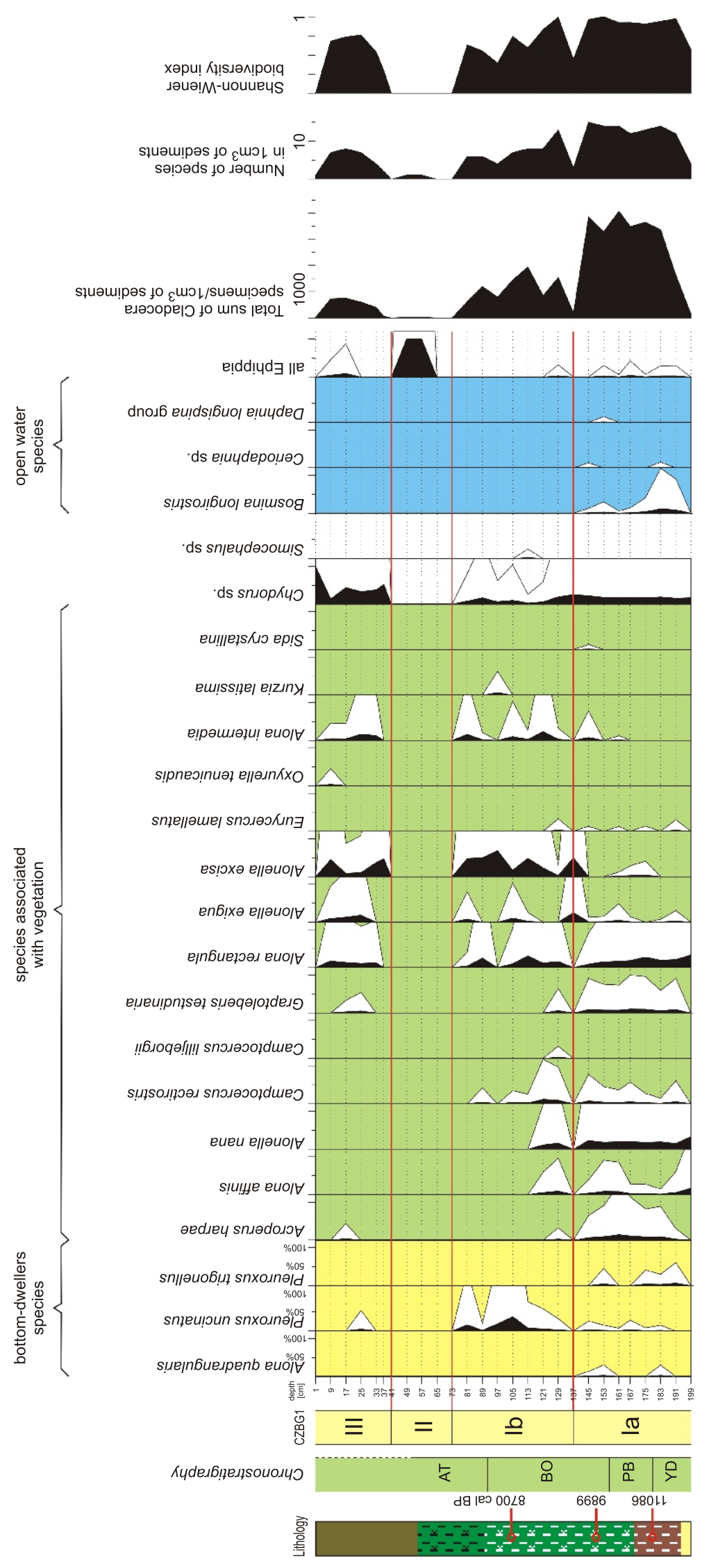

Fig. 5. Relative abundance diagram of subfossil cladoceran taxa and diagram of total number of Cladocera specimens, number of species diversity in the sediments of the BG-1 profile

CZBG-1 - Cladocera assemblage zones; other explanations as in Figure 4 sion of Filipendula ulmaria, which needs average July temperatures to be $>16^{\circ} \mathrm{C}$ (Aarnes et al., 2012). Macrophytes such as Nymphaea alba and Ceratophyllum demersum grew in the lake (Fig. $3)$. An increasing frequency of cyanobacteria Anabaena is observed while planktonic species of green algae Pediastrum were decreasing;

Wk-3 (163-123 cm, Boreal). In rush vegetation, Filicales monolete spores predominate. There is higher frequency of Typha latifolia and lower frequency of macrophytes.

Wk-4 (123-83 cm, Boreal). Increasing frequency of Cyperaceae pollens as well as the presence of fungal spores Sordaria and HdV-200 , which was synchronous with the decreasing frequency of Filicales monolete spores, recorded at a depth of 111-95 cm.

Wk-5 (83-55 cm, Atlantic). In plant communities Filicales monolete spores are prevalent, which is reflected in the higher frequency of Thelypteris palustris spores (Fig. 4). As in the previous phase, there was a high occurrence of Turbellaria.

\section{GEOCHEMICAL ANALYSIS}

Five geochemical zones were distinguished in borehole BG-1 using cluster analysis (Fig. 4). Zone I $(195-170 \mathrm{~cm})$ consists of dark coloured detritus gyttja that accumulated during the Younger Dryas and Preboreal periods. The gyttja displays increasing carbonates $(7.8-13.7 \%)$, TOC $\left(63.82-257.59 \mathrm{~g} \cdot \mathrm{kg}^{-1}\right)$ and N (3.91-20.96 $\left.\mathrm{g} \cdot \mathrm{kg}^{-1}\right)$. The lake mud in borehole BG-2 at the same depth interval contains $34.17-106.48 \mathrm{~g} \cdot \mathrm{kg}^{-1}$ of TOC and $1.46-6.09 \mathrm{~g} \cdot \mathrm{kg}^{-1}$ of $\mathrm{N}$. Both deposit types are poor in phosphorus $\left(0.37-1.18 \mathrm{~g}^{\circ} \mathrm{kg}^{-1}\right.$ in gyttja and $0.28-0.48 \mathrm{~g}^{\cdot \mathrm{kg}^{-1}}$ in mud) and relatively poor in $\mathrm{K} \quad\left(3.10-4.28 \mathrm{~g} \mathrm{~kg}^{-1}\right.$ in gyttja and $1.88-5.77 \mathrm{~g} \cdot \mathrm{kg}^{-1}$ in mud), Fe (8.09-11.88 $\mathrm{g}^{\cdot \mathrm{kg}^{-1}}$ in gyttja and $5.00-15.14 \mathrm{~g} \cdot \mathrm{kg}^{-1}$ in mud) and Al $\left(9.64-12.85 \mathrm{~g} \mathrm{~kg}^{-1}\right.$ in gyttja and 5.33-14.82 $\mathrm{g} \mathrm{kg}^{-1}$ in mud).

Zone II $(170-140 \mathrm{~cm})$ represents the initial phase of reed peat accumulation during Preboreal times and the beginning of Boreal times. It is characterized by decreasing $\mathrm{pH}$ from 7.2 to 5.8 and decreasing values of $\mathrm{K}\left(2.75-0.93 \mathrm{~g} \cdot \mathrm{kg}^{-1}\right)$, $\mathrm{Mg}\left(3.21-1.37 \mathrm{~g} \mathrm{~kg}^{-1}\right)$ and $\mathrm{Al}\left(8.78-3.15 \mathrm{~g}^{\cdot \mathrm{kg}^{-1}}\right)$ (Fig. 4). TOC and $\mathrm{N}$ values increase. The TOC:N ratios are from 15:1 to 19:1.

Zone III $(140-90 \mathrm{~cm})$ represents the second phase of reed peat accumulation. The peat is characterized by high amounts of TOC and N, which in the borehole BG-1 are 463.63-549.46 g. $\cdot \mathrm{kg}^{-1}$ and $23.04-27.35 \mathrm{~g} \cdot \mathrm{kg}^{-1}$ respectively; and a stable $\mathrm{pH}$ from 5.6-5.8. The contents of $\mathrm{Na}$ $\left(0.31-0.40 \mathrm{~g} \cdot \mathrm{kg}^{-1}\right), \mathrm{K}\left(0.06-0.35 \mathrm{~g} \cdot \mathrm{kg}^{-1}\right), \mathrm{Mg}$ $\left(0.67-0.94 \mathrm{~g} \cdot \mathrm{kg}^{-1}\right)$, Al $\left(0.26-1.50 \mathrm{~g} \cdot \mathrm{kg}^{-1}\right), \mathrm{Mn}$ $\left(100.83-169.23 \mathrm{mg} \cdot \mathrm{kg}^{-1}\right), \mathrm{Cu}\left(6.23-9.58 \mathrm{mg} \cdot \mathrm{kg}^{-1}\right)$ and $\mathrm{Zn}\left(4.28-15.89 \mathrm{mg} \cdot \mathrm{kg}^{-1}\right)$ are in general low and show only small variation in most cases.

Zone IV (90-35 cm) constitutes a succession of terrestrial vegetation that grew during the Atlantic period, which is reflected in the presence of al- 
der peat. The zone is characterized by large amounts of TOC (458.88-495.76 $\left.\mathrm{g}^{\mathrm{kg}} \mathrm{g}^{-1}\right)$ and increasing contents of $\mathrm{N}$ $\left(22.09-29.62 \mathrm{~g} \cdot \mathrm{kg}^{-1}\right)$ and $\mathrm{P}(0.30-0.83$ $\mathrm{g} \cdot \mathrm{kg}^{-1}$ ), whereas the TOC:N and TOC:P ratios decrease (from 22:1 to $16: 1$ and from 1648:1 to 531:1 respectively: Fig. 4). The values of $\mathrm{Na}\left(0.28-0.35 \mathrm{~g} \cdot \mathrm{kg}^{-1}\right), \mathrm{K}$ $\left(0.09-0.32 \mathrm{~g} \cdot \mathrm{kg}^{-1}\right), \mathrm{Mg}\left(0.78-1.04 \mathrm{~g} \cdot \mathrm{kg}^{-1}\right)$, Al (1.02-4.12 $\left.\mathrm{g}^{\mathrm{kg}}{ }^{-1}\right), \mathrm{Mn}(186.70-226.13$ $\left.\mathrm{mg} \cdot \mathrm{kg}^{-1}\right)$ and $\mathrm{Zn}\left(2.48-12.26 \mathrm{mg} \cdot \mathrm{kg}^{-1}\right)$ are relatively stable over time and do not differ significantly from those of zone III.

Zone V $(35-0 \mathrm{~cm})$ represents strongly decomposed alder peat, of which the younger dates probably relate to the end of the Atlantic period. It is characterized by increasing $\mathrm{pH}$ (5.6-6.9) and amounts of $\mathrm{P}\left(0.75-3.49 \mathrm{~g} \cdot \mathrm{kg}^{-1}\right)$, Na $(0.38-0.98$ $\left.\mathrm{g} \cdot \mathrm{kg}^{-1}\right), \mathrm{Mn}\left(157.05-359.19 \mathrm{mg} \cdot \mathrm{kg}^{-1}\right), \mathrm{Cu}$ $\left(11.45-17.31 \mathrm{~g}^{\circ} \mathrm{kg}^{-1}\right)$ and $\mathrm{Zn}(9.63-66.98$ $\left.\mathrm{g} \cdot \mathrm{kg}^{-1}\right)$. The contents of the remaining elements are relatively stable over time.

\section{CLADOCERA ANALYSIS}

25 species of Cladocera were identified in the boreholes investigated (22 species in borehole BG-1 and 23 in borehole BG-2), which belong to four families: Chydoridae, Sididae, Bosminidae and Daphnidae. Between these two profiles are minor differences in species content (Figs. 5 and 6). In borehole BG-1 Daphnia longispina-group and Camptocercus lilljeborgii were recorded, while these were absent in borehole BG-2. On the other hand, in borehole BG-2 Disparalona rostrata, Peracantha truncata and Alona guttata were found, these not being identified in borehole BG-1. Among the species found in the sediments, the vast majority was species inhabiting the littoral zone (22) living on the bottom and among the water plants; only Bosmina longirostris, Daphnia longispina-group and Ceriodaphnia sp. could be counted as pelagic species. Three main zones, and two subzones of the Cladocera succession, were distinguished in each borehole based on changes in the frequency and number of species preserved, and indicator species. The zones are described in Tables 4 and 5.

COMPARISON OF THE ZONES OF CLADOCERA ASSEMBLY DEVELOPMENT IN PROFILES BG-1 AND BG-2

The beginning of Zone la constitutes a record of the initial stage of lake development (Figs. 5 and 6). This zone is characterized by the highest number of species and individuals of Cladocera but only

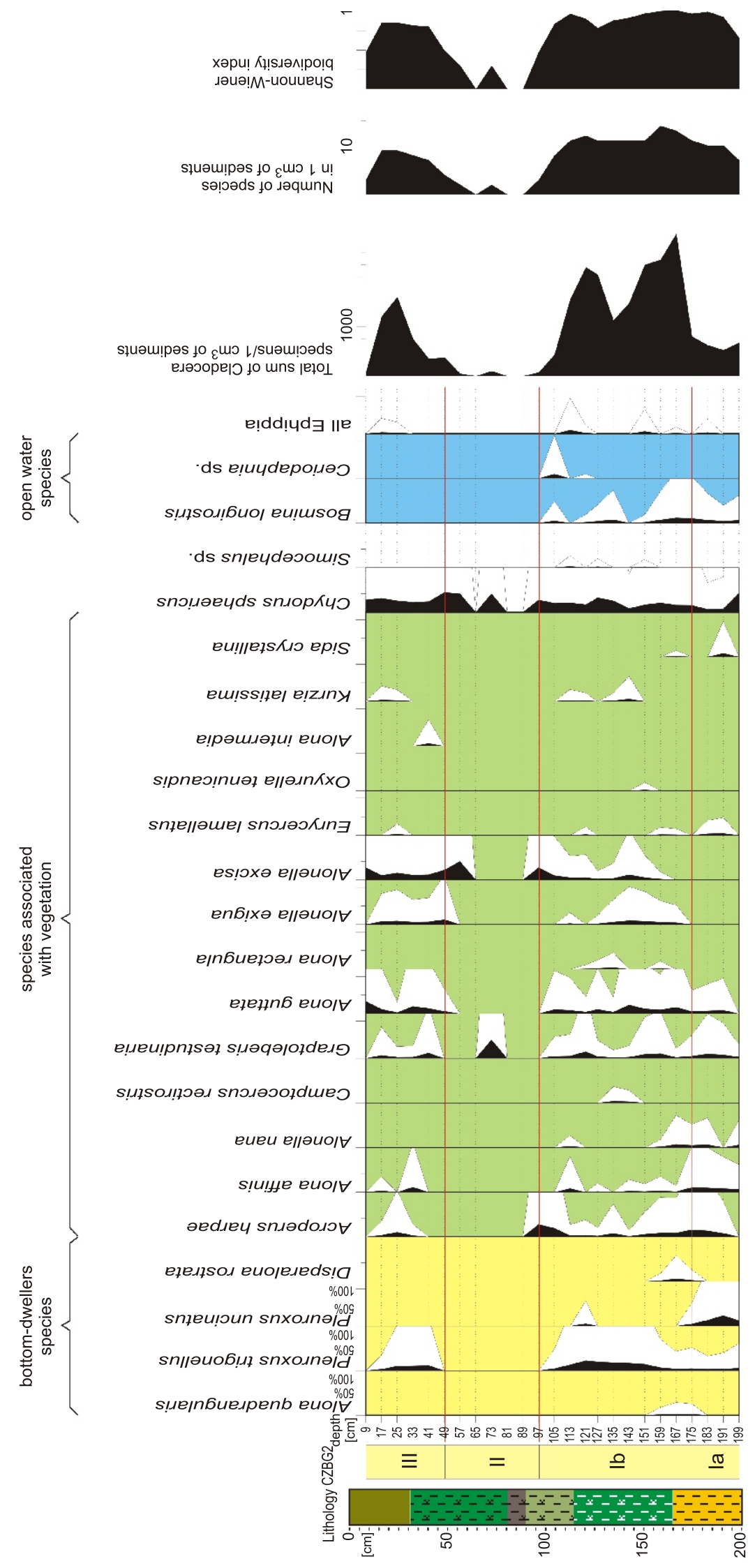

Fig. 6. Relative abundance diagram of subfossil cladoceran taxa and diagram of total number of Cladocera specimens, number of species diversity in the sediments of the BG-2 profile

CZBG-2 - Cladocera assemblage zones; other explanations as in Figure 4 
Radiocarbon dating results, borehole BG-1

\begin{tabular}{|l|c|c|c|c|c|}
\hline No. & $\begin{array}{c}\text { Depth } \\
{[\mathrm{cm}]}\end{array}$ & $\begin{array}{c}\text { Dated } \\
\text { material }\end{array}$ & $\begin{array}{c}\text { No. of } \\
\text { dates }\end{array}$ & $\begin{array}{c}\text { Results of dates } \\
\text { in }{ }^{14} \mathrm{C} \text { yr. BP }\end{array}$ & $\begin{array}{c}\text { Calibrated ages } \\
\text { in cal. yr. BP }\end{array}$ \\
\hline 1. & $104-106$ & peat & MKL-2104 & $8100 \pm 90$ & 8700 \\
\hline 2. & $147-149$ & peat & MKL-2105 & $9050 \pm 100$ & 9899 \\
\hline 3. & $177-179$ & detritus & MKL-2106 & $9840 \pm 90$ & 11086 \\
\hline
\end{tabular}

Description of local pollen assemblage zones (LPAZ), profile BG-1

\begin{tabular}{|l|c|c|c|}
\hline \multicolumn{1}{|c|}{$\begin{array}{c}\text { Symbol and name } \\
\text { of pollen zone }\end{array}$} & Period & $\begin{array}{c}\text { Depth } \\
{[\mathrm{cm}]}\end{array}$ & Main features of pollen spectra \\
\hline $\begin{array}{l}\text { Wk-I } \\
\text { (Artemisia-Poaceae-Juniperus) }\end{array}$ & Late Glacial & $199-187$ & $\begin{array}{c}\text { High values of Artemisia, Juniperus, and Poaceae pollen; } \\
\text { Ranunculus acris-t. Occurs regularly }\end{array}$ \\
\hline $\begin{array}{l}\text { Wk-II } \\
\text { (Betula-Pinus) }\end{array}$ & Preboreal & $187-155$ & $\begin{array}{c}\text { Very high proportion of Betula pollen; gradually increasing values } \\
\text { of Pinus sylvestris type; Poaceae pollen occurs regularly; } \\
\text { the first appearance of Filipendula ulmaria pollen }\end{array}$ \\
\hline $\begin{array}{l}\text { Wk-III } \\
\text { (Corylus-Pinus) }\end{array}$ & Boreal & $155-99$ & $\begin{array}{c}\text { Rises in values of Pinus sy/vestris type and decreasing values } \\
\text { of Betula and Poaceae; first appearance of Corylus; Fraxinus and Ulmus } \\
\text { Filicales monolete spores are present. }\end{array}$ \\
\hline $\begin{array}{l}\text { Wk-IV } \\
\text { (Pinus-Alnus-Quercus) }\end{array}$ & Atlantic & $99-55$ & $\begin{array}{c}\text { Maximum values of Pinus pollen; low values of Betula and Corylus; } \\
\text { first appearance of Quercus and Tilia pollen; rising values of Alnus }\end{array}$ \\
\hline
\end{tabular}

Description of assemblage zones distinguished in profile BG-1, on the basis of pollen taxa of aquatic, mire plants and non-pollen palynomorphs (NPPs)

\begin{tabular}{|l|c|c|c|}
\hline \multicolumn{1}{|c|}{$\begin{array}{c}\text { Symbol and name } \\
\text { of zone }\end{array}$} & $\begin{array}{c}\text { Symbol and name } \\
\text { RPAZ }\end{array}$ & $\begin{array}{c}\text { Depth } \\
\text { [cm] }\end{array}$ & Main features of pollen spectra \\
\hline Wk-1 & Late Glacial & $199-195$ & $\begin{array}{r}\text { High proportion of Pediastrum; single pollen grains of Myriophyllum } \\
\text { spicatum; decreasing curve of Cyperaceae }\end{array}$ \\
\hline Wk-2 & YD/Preboreal & $195-163$ & $\begin{array}{c}\text { Maximum of Ceratophyllum-haris, Nympheae alba, Equisetum; decreasing } \\
\text { curve of Pediastrum sp.; rise of Filicales monolete spores }\end{array}$ \\
\hline Wk-3 & Boreal & $163-123$ & $\begin{array}{c}\text { Single pollen grains of Typha latifolia and single spores of fungi HdV-200 } \\
\text { and Persicispora; rising curve of Filicales monolete spores }\end{array}$ \\
\hline Wk-4 & Boreal & $123-83$ & $\begin{array}{c}\text { Rising curve of Cyperaceae and decreasing curve of Filicales monolete; } \\
\text { high proportion of HdV-200 and Sordaria; frequent occurrence } \\
\text { of Nymphaea alba }\end{array}$ \\
\hline Wk-5 & Atlantic & $83-55$ & Maximum of Filicales monolete spores; low proportion of Cyperaceae; \\
rise of Turbellaria curve
\end{tabular}

in the deepest part of the oxbow lake that was better supplied in the water (BG1 - Fig. 5). A gradually increase in the occurrence of species indicated a higher fertility of water and abundance of nutrients: Alona rectangula, Chydorus sphaericus (Alhonen, 1970) and the species Pleuroxus uncinatus, Pleuroxus trigonellus and Disparalona rostrata (Whiteside, 1970). Remains of species characterized by high thermal requirements were also found, e.g. Camptocercus rectirostris, Pleuroxus sp., Graptoleberis testudinaria (Poulsen, 1944). Species living in different environments were noted e.g., associated with bottom sediments (Alona quadrangularis) and aquatic plants (Acroperus harpae, Alona affinis, Alonella nana). A high number of individuals, which exceeded 4000 individuals $/ \mathrm{cm}^{3}$ of sediment, was noted. In the palaeochannel neck, where mud accumulated, the Cladocera species composition was similar, but poorer with a much smaller number of individuals, which did not exceed 800 individuals $/ \mathrm{cm}^{3}$ of sediment. In both boreholes several increases in the number of the remains of species from the open-water group were identified e.g., Bosmina longirostris, Ceriodaphnia sp., and Daphnia longispina-group.

Zone $\mathrm{lb}$ is developed differently in the two boreholes. A vast improvement in the conditions for development took place in the part located closer to the palaeochannel neck (BG-2 - Fig. 6). Greatly increased numbers of species were noted (to 22), the number of individuals reaching almost 3000 individuals $/ \mathrm{cm}^{3}$ of sediment. The main species indicated a higher fertility of the waters: Pleuroxus trigonellus, Chydorus sphaericus, Alona rectangula, Bosmina longirostris, Graptoleberis testudinaria, Disparalona rostrata and mesotrophic status - Alonella exigua and Alonella trigonellus (Adamska and Mikulski, 1968). There was a relatively high number of species associated with water plants: Acroperus harpae, Alonella nana, Alonella excisa (Flössner, 1964). Certain species were also present that indicated a higher water level: Bosmina longirostris and Ceriodaphnia sp. 
Description of Cladocera assemblage zones (CZBG-1) distinguished in profile BG-1

\begin{tabular}{|c|c|c|}
\hline Symbol & $\begin{array}{l}\text { Depth } \\
\text { [cm] }\end{array}$ & Main features of Cladocera spectra \\
\hline CZBG-1 la & 199-137 & $\begin{array}{l}\text { The best development conditions for the zooplankton. } 18 \text { species were identified (Fig. 5). The total number of indi- } \\
\text { viduals of Cladocera recorded is around } 4080 \text { specimens in } 1 \mathrm{~cm}^{3} \text { of sediment. In this zone there was the maxi- } \\
\text { mum number of species and individuals. Predominant species: Alona rectangula (max. 33\%), Alonella nana } \\
\text { (max. 33\%), Chydorus sphaericus (max. 22\%), Alona affinis (max. 17\%), Acroperus harpae (max. 15\%). Species } \\
\text { from different habitat groups occurred. High occurrence of species from the open water zone (max. 13\% - all spe- } \\
\text { cies). Highest index of biodiversity (1.0) in the lake (Fig. 5). }\end{array}$ \\
\hline CZBG-1 lb & 137-73 & $\begin{array}{l}\text { Deterioration of living conditions in the lake. Decreasing abundance of specimens (max. } 1950 \mathrm{sp} . / \mathrm{cm}^{3} \text { of sedi- } \\
\text { ment) and species (15). Main species are connected with water plants: Alona rectangula ( } 31 \% \text { ), Alona intermedia } \\
\text { (max. 24\%), Camptocercus rectirostris (max. } 12 \% \text { ) and dominant species Alonella excisa (max. } 69 \% \text { ) which is } \\
\text { also tolerant of lower pH. High abundance of one species Pleuroxus uncinatus (max. } 38 \% \text { ) connected with sedi- } \\
\text { ment and ubiquitous Chydorus sphaericus (max. } 20 \% \text { ). Lack of species from open water zone. Biodiversity index } \\
\text { was high at the beginning of the zone and then dropped to } 0.6 \text {. }\end{array}$ \\
\hline CZBG-1 II & $73-41$ & Scarcity of Cladocera remains in the sediment; only a few Cladocera ephippia were identified. \\
\hline CZBG-1 III & $41-1$ & $\begin{array}{l}\text { Slight improvement of conditions for zooplankton development. Increase in frequency of species to } 9 \text { (Fig. 5). In- } \\
\text { crease in occurrence of specimens: }>750 \text { individuals of Cladocera in } 1 \mathrm{~cm}^{3} \text { of sediment. Main species are con- } \\
\text { nected with water plants: Alonella excisa (max. } 45 \% \text { ), Alona rectangula (18\%) Alona intermedia (max. 17\%) and } \\
\text { Chydorus sphaericus ( } 52-100 \% \text { at the end). }\end{array}$ \\
\hline
\end{tabular}

Description of Cladocera assemblage zones (CZBG-2) distinguished in profile BG-2

\begin{tabular}{|c|c|c|}
\hline Symbol & $\begin{array}{l}\text { Depth } \\
\text { [cm] }\end{array}$ & Main features of Cladocera spectra \\
\hline CZBG-2 la & $199-175$ & $\begin{array}{l}\text { In this zone the presence of } 13 \text { species of Cladocera was determined (Fig. } 6 \text { ). The total frequency amounted to } \\
525-800 \mathrm{sp} . / \mathrm{cm} \text { of sediment. Species from all habitat groups were found. Chydorus sphaericus predominated, } \\
\text { with max. } 52 \% \text { contribution. There were also numerous specimens of species such as: Pleuroxus uncinatus } \\
\text { (max. } 29 \% \text {, Acroperus harpae (max. 19\%), Alona affinis and Bosmina longirostris (max. 13\%). The biodiversity } \\
\text { index was } 0.66 \text { at the beginning and increased to } 0.99 \text {. }\end{array}$ \\
\hline CZBG-2 lb & 175-97 & $\begin{array}{l}\text { The best zone for Cladocera development. } 22 \text { species were identified. Total number of individuals of Cladocera in } \\
\text { the sediments was above } 2850 \text { sp./cm of sediment. In this zone there was the maximum number of species and } \\
\text { individuals. Predominant species: ubiquitous Chydorus sphaericus (max. } 52 \% \text { ), Pleuroxus uncinatus (max. } \\
29 \% \text { ), Acroperus harpae (max. 19\%), Alona affinis (max. 13\%) and Bosmina longirostris (max. 13\%). The main } \\
\text { species were connected with sediments and associated with macrophytes. Species from the open water zone } \\
\text { were found. The biodiversity index was about 1.0. }\end{array}$ \\
\hline CZBG-2 II & $97-49$ & $\begin{array}{l}\text { Significant deterioration of living conditions in the lake. Decreasing abundance of specimens ( }<250 \mathrm{sp} \text {./g of sedi- } \\
\text { ment) and species (3). Predominant Graptoleberis testudinaria (max. 49\%) and widely tolerant Chydorus } \\
\text { sphaericus (max. } 51 \% \text { ). Lack of Cladocera from the open water zone. }\end{array}$ \\
\hline CZBG-2 III & $49-9$ & $\begin{array}{l}\text { Improvement of development conditions. Increase in the frequency of species to } 11 \text { and in the occurrence of } \\
\text { specimens: }>1600 \mathrm{sp} \text {./cm } \mathrm{cm}^{3} \text { of sediments (Fig. } 6 \text { ). Predominant species connected with water plants: Alonella } \\
\text { excisa (max. 33\%), Alona guttata (33\%) Alona affinis (max. } 13 \% \text {, Graptoleberis testudinaria (max. } 14 \% \text { ), } \\
\text { Pleuroxus trigonellus (max. } 14 \% \text { ) - connected with sediment and Chydorus sphaericus (max. 33\%). Lack of } \\
\text { Cladocera from the open water zone. }\end{array}$ \\
\hline
\end{tabular}

In the middle part of the lake (BG-1 - Fig. 5) there was noted a decline in the number of Cladocera remains. Initially, the number of species was 15 , then decreased to 9 . Alonella excisa predominated: a species that dwells on aquatic plants reeds and watermilfoil (Myriophyllum) and Pleuroxus trigonellus - living on the bottom, similar to $A$. excisa, showing a high tolerance to low pH (Krause-Dellin and Steinberg, 1986). High occurrences were also noted for two species resistant to environmental stress associated with a lowering of water level: Chydorus sphaericus and Alona rectangula. At the end of Zone la there appeared the species Alona intermedia, continuing its occurrence into Zone lb. There was a lack of species typical of open water.

Zone $\mathrm{lb}$ of borehole BG-2 is coincident with Zone $\mathrm{lb}$ in the BG-1 borehole, with a comparable number of species, but a smaller number of individuals of Cladocera (Figs. 5 and 6 ). In both parts of the lake there occurred species associated with the bottom and with aquatic plants. Species from the open water zone are found only in Zone la of borehole BG-1 and in subzones la and Ib of borehole BG-2. In both parts of the lake there occurred species associated with bottom and aquatic plants.

Remains of Cladocera probably accumulated in both profiles at the same time but in different hydrological situations, affected by the slightly different compositions and numbers of Cladocera. In both profiles at the end of Zone lb there was a retreat from the lake of almost all species of Cladocera.

Zone II was associated with a lack of identified Cladocera remains in borehole BG-1, represented only by a few ephippia, i.e. the resting eggs of Cladocera. In the BG-2 borehole (Fig. 6) this zone is characterized by the presence of only one species (Chydorus sphaericus), of very broad environmental tolerance. At the beginning of this zone, Alonella excisa occurred in the lake, dwelling among water plants and also resistant to low $\mathrm{pH}$, 
similarly to Ch. sphaericus (Krause-Dellin and Steinberg, 1986). In the middle part of this zone there appeared Graptoleberis testudinaria (Rybak and Błędzki, 2010).

Zone III represents improving conditions of Cladocera development, which is reflected in the increasing number of species to nine in borehole BG-1 (Fig. 5) and to 10 in borehole BG-2 (Fig. 6), also associated with an increase in the number of individuals, up to 750 and 1600 respectively. The predominant species lived on submerged plants and sediments. The most frequent were: Ch. sphaericus, Alona excisa, Alona rectangula and Pleuroxus sp. These species are resistant to low $\mathrm{pH}$, low water level and may be found in peat bogs and in dystrophic lakes (Duigan, 1992; Rybak and Błędzki, 2010).

\section{DISCUSSION}

\section{RECONSTRUCTION OF OXBOW LAKE DEVELOPMENT IN THE WKRA RIVER VALLEY NEAR BELAWY GOŁUSKIE}

River meanders provide evidence of major environmental dynamics of river valley geosystems. Specific aquatic-mire ecosystems develop in oxbow lakes after cut-off from the river, characterized over time by variable intensity of river and groundwater supply, these being strongly controlled by climatic conditions. Periodic supply of river water, carrying a variety of suspended and dissolved substances, plays an important role in the functioning of these ecosystems, particularly strongly influencing planktonic organisms and aquatic plant communities. During their development, oxbow lakes gradually fill with stratified mineral and organic sediments of varied origins and properties, which constitute a geochemical and palaeogeographical record of the oxbow lake and its catchment evolution (Pawło- wski et al., 2015a). However, they have rarely been used for purposes of palaeoenvironmental reconstructions.

The usefulness of palaeo-oxbow lake sediments for palaeoenvironmental reconstructions suggested by Pawłowski et al. (2015a) is confirmed by our studies in the valley of the Wkra River. Based on geochemical, pollen and fossil Cladocera analysis, supported by radiocarbon dating, we reconstructed the period of oxbow lake formation and its cut-off from the river, as well as the temporal dynamics of ecological conditions in the reservoir and its catchment. The main stages of evolution reconstructed are described below.

Younger Dryas (LPAZ-Wk-I; zone Wk-1, 2; geochemical zone I; Cladocera - beginning of la CZBG-1 and la CZBG-2, Fig. 7). Steppe vegetation, indicating dry and cold climate conditions, probably predominated in the vicinity of the newly formed oxbow lake at the close of the Younger Dryas. In the open forests birch (Betula) and pine (Pinus) predominated, whereas grasses (Poaceae), sagebrush (Artemisia) and shrubs, particularly juniper (Juniperus) covered open spaces. In the deeper zone of the lake (borehole BG-1) detritus gyttja was accumulating, which contained organic matter and carbonates that increased with time. Probably during the same period in the neck of oxbow lake, fine-grained mineral sediments were accumulating, carried in by river waters (Fig. 7). The spatial variability in sediment properties indicates varied ecological conditions in the individual zones of the lake in the initial phase of its development, and highlights the importance of spatial studies in palaeoenvironmental reconstructions. A considerable depth of the lake is shown by the presence of Cladocera taxa typical of open waters, such as Bosmina longirostris and Ceriodaphnia sp. Frequently occurring species of Pediastrum are relatively abundant in nitrogen-rich sediments, indicating the presence of a moderately deep, eutrophic water body, which was continuously supplied with biogenic substances from river waters.

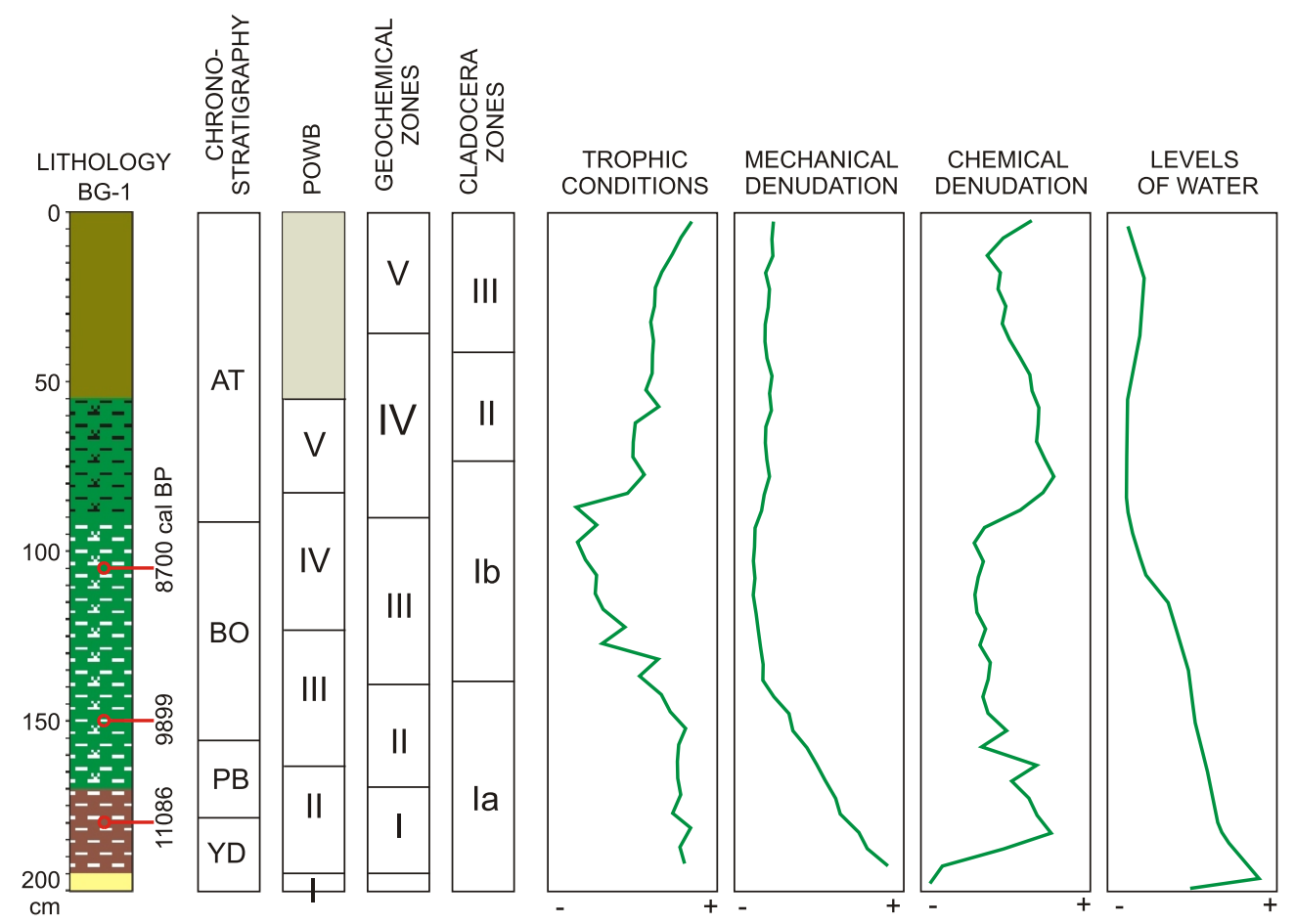

Fig. 7. Comparison of the palaeohydrological data for the profile BG-1 based on pollen, geochemical and Cladocera analysis 
Such conditions favoured the development of Cladocera, which is supported by the increasing frequency of different ecological groups of these organisms, especially of species with high trophic requirements (viz. Alona rectangula, Chydorus sphaericus, Pleuroxus trigonellus). Species were also observed with higher thermal requirements - Pleuroxus sp., Graptoleberis testudinaria, Camptocercus rectirostris, which belong to south temperate species (Hofmann, 2000; Szeroczyńska and Zawisza, 2007). These species have also been noticed in other water bodies from the Younger Dryas, including in the palaeo-oxbow lakes of Korzeń and Kolonia Bechcice and Gościąz Lake (Szeroczyńska and Zawisza, 2007; Pawłowski, 2012). The presence of thermophilic species (Typha latifolia) is probably associated with periodic increases in temperature during the Younger Dryas, when minimum average July temperatures increased - to $13^{\circ} \mathrm{C}$ (Ralska-Jasiewiczowa et al., 2004) while the presence of the hydrophyte Myriophyllum spicatum indicates that the temperature was above $10^{\circ} \mathrm{C}$ (Bos et al., 2007).

Preboreal (LPAZ - Wk-II; zone Wk-2, 3; geochemical zone II; Cladocera - mid part CZGB-1 la, beginning CZGB-2 lb). A general tendency to climate warming at the close of the Younger Dryas and beginning of Holocene times in the area of Central Europe, and related decrease of water level in inland reservoirs (Magny and Bégeot, 2004; Bos et al., 2007), is supported by the appearance of Ceratophyllum demersum, Nymphaea alba and Typha latifolia in aquatic and rush plant assemblages. The relatively intense development of these species suggests average July temperatures of $13-15^{\circ} \mathrm{C}$ (Isarin and Bohncke, 1999; Ralska-Jasiewiczowa et al., 2004; Bos et al., 2007), which is also shown by the presence of thermophilic Cladocera (Pleuroxus sp., Camptocercus rectirostris). A considerable decrease of water level during this period was noticed also by Karasiewicz et al. (2014) in Retno Lake and Zawiska et al. (2015) in Łukie Lake. This increase of temperatures resulted in an increasing frequency of both individuals and species of Cladocera. Groups of species were represented that are associated with aquatic plants and bottom sediments. The highest frequencies involved also species of higher trophic requirements: Alona rectangula, Ch. sphaericus, Pleuroxus trigonellus, and Anabaena predominated within algae. This was probably the period most favourable for Cladocera development in the lake studied. Such a situation was noticed in most of the lakes investigated in Poland (e.g., Milecka and Szeroczyńska, 2005; Szeroczyńska, 2006). In the second half of the Preboreal period, a lowering of water level took place in the oxbow lake, which is reflected in the change of sediment type. Accumulation of organic-rich reed peat began. At the same time, the frequency of Cladocera species typical of open waters, including Bosmina longirostris and Alona quadrangularis, decreased. In the sediments there appeared fungal spores of Persicispora sp. genus and HdV-200, which may be present in decaying wood and remains of plants associated with temporarily drying water bodies (Van Geel et al., 1989; Kuhry, 1997; Aptroot and Van Geel, 2006). The vertical variability in the chemistry of the deposits from this period (e.g., increasing content of nitrogen and phosphorus, decreasing amounts of components associated with the mineral phase, increasing values of TOC:N and TOC:P) suggests a gradual deterioration of trophic conditions (Fig. 7), which is probably due to the decreasing role of river waters in supplying the lake (reflected also in the decreasing trends in $\mathrm{K}$ and $\mathrm{Al}$ content).

Boreal (LPAZ - Wk-III; zone Wk-3, 4; geochemical zone II; Cladocera - end of la CZBG-1, mid part Ib CZBG-2). An expansion of hazel (Corylus avellana) at approximately $9899 \mathrm{cal}$. $\mathrm{BP}$ is observed. This is typical for many areas in Europe, dated to about 10,500 cal BP, and climate warming is considered as the major factor determining the expansion of this species (Finsinger et al., 2006; Giesecke et al., 2011). At the beginning of the Boreal period, forests were dominated by pine (Pinus), which gradually displaced birch (Betula). In riparian forests there appeared elm (UImus) and willow (Salix), which occurred within wetlands. The presence of Filipendula ulmaria suggests a progressive warming of climate (Aarnes et al., 2012). Conditions were highly favourable for zooplankton development. In the oxbow lake studied, we can see the reappearance of species typical of open waters, which indicates an increase in water level. At the beginning of this period, the high frequency of species inhabiting the area among aquatic plants Alonella nana, Acroperus harpae, Alona affinis, and having higher thermal and trophic requirements, persists. The increasing frequency of Cyperaceae pollen, as well as of fungal spores of Sordaria and HdV-200 in sediments at depths of $95-111 \mathrm{~cm}$, indicates a drier period. This is also shown by the decrease of Filicales monolete spore frequency and a considerable decrease in Cladocera species diversity, especially in the lack of species associated with open waters. In parallel, we can see an increasing frequency of species resistant to low $\mathrm{pH}$ (Alonella excisa). In this period, the oxbow lake was completely cut-off from the river, which is also shown by the large and uniform amounts of organic matter in the reed peat, as well as in the lowest concentrations of $\mathrm{Al}, \mathrm{K}$ and $\mathrm{Mn}$ within the boreholes. The low contents of these elements suggest a low intensity of mechanical denudation in the catchment (Borówka, 2007; Fig. 7). The relatively high contents of $\mathrm{Ca}$ show the important role of groundwater in lake supply. The progressive increases in TOC:N and TOC:P ratios indicate a deterioration of trophic conditions. The drying of climate from this period is also reflected in isotopic data from Charzykowskie Lake (Mirosław-Grabowska and Zawisza, 2014).

Atlantic period (LPAZ - Wk-IV; zone Wk-5; geochemical zone 4; Cladocera - CZGB-1 - end Ib,II, III; CZGB-2 - II, III). From the beginning of the Atlantic period, about 8,700 cal. BP, an expansion of alder (Alnus) is observed within the lake catchment. This process had a synchronous character in the Baltic Sea region due to favourable habitat conditions within postglacial areas (Giesecke et al., 2011). New tree species (Tilia, Fraxinus, Quercus) appeared, which indicate the improvement of climatic and edaphic conditions. A radical change in ecological conditions of the lake took place in this phase, including a considerable decline in water level. At the beginning of this period, the lake was surrounded by a line of rush vegetation with Thelypteris palustris. Peat from this period is characterized by only a slightly lower content of organic matter compared to the previous one. Increasing contents of nitrogen and phosphorus and narrowing values of the TOC:N and TOC:P ratios are indices of growing trophic character of the lake. Groundwater still played a predominant role in its supply. At the beginning of the Atlantic period, the reservoir was inhabited by the species of Cladocera most resistant to environmental stress, including Chydorus sphaericus, Alonella excisa, Alona rectagula and Pleuroxus sp. (Duigan, 1992); however, in the next period (CZBG-1 III, CZBG-2 III), almost every one of these retreated. This left only the most tolerant species: Chydorus sphaericus. The presence of ephippia (resting eggs of Cladocera) also suggests the unfavorable environmental conditions (Sarmaja-Karjonen, 2003). At the end of the lake development, an increase in Cladocera frequency took place several times, especially for species with wide environmental tolerance, which could indicate periodic supply of river water. During this period, lake waters were eutrophic in their character, which is sup- 
ported by the presence of Turbellaria. The data obtained do not allow us precisely to delineate the timing of lake disappearance. It probably took place at the close of the Atlantic period.

Geochemical features of the top of sediments have been strongly modified by human activity during the last few centuries. Strong decomposition of peat mass as a result of drainage works and Wkra River channel straightening in the 20th century, and elevated concentrations of phosphorus and heavy metals, are the most perceptible signs of this impact.

\section{CONCLUSIONS}

Our study shows the importance of palaeo-oxbow lakes as archives of river valley environmental evolution. Based on geochemical and palaeogeographical analyses, we have reconstructed some important aspects of the Late Pleistocene and Holocene evolution of the Wkra River Valley environment within the area studied. The results illustrating the spatiotemporal dynamics of the aquatic-mire ecosystem provide information to help reconstruct the period of oxbow lake formation and its cut-off from the river, hydrological conditions within the catchment, the intensity of mechanical and chemical denudation, as well as some aspects of the influence of human activity (Fig. 7). We distinguished dry and wet phases in lake development and made an attempt to correlate these with other stands from Poland, and widely discussed episodes of climatic change. The most important findings arising from our study are the following:

- Cut-off from the river of the meander took place during the Younger Dryas. However, the newly formed oxbow lake was supplied by river water until the beginning of Boreal times.

- Water level fluctuations in the lake related to general tendencies observed in river valleys on the Polish Plain. During the Younger Dryas and the beginning of Holocene time, there occurred periods of high water levels, whereas at the close of Boreal time and the beginning of Atlantic time, we noticed a decrease in water level. The record of a dry phase from about 8100 cal BP is very clear.

- The lake in its initial phase of development was supplied mainly by river water, the importance of which de- creased over time. From the beginning of Boreal time, groundwater played the major role in reservoir supply. This is confirmed both by the vertical variability of geochemical features of the sediments and the subfossil Cladorera and pollen contained within them.

- The intensity of mechanical denudation in the lake catchment was in general low, which is supported by the significant content of organic matter and lack of $\mathrm{Al}, \mathrm{K}$ and $\mathrm{Mn}$ in the sediment boreholes.

- The vertically variable contents of TOC, $\mathrm{N}$ as well as TOC: $N$ and TOC:P ratios in the sediment boreholes, reflect the temporal variability in the trophic conditions of the lake, which were strongly affected by the source of water supply. In the initial phase of development, it was a eutrophic reservoir supplied by river water rich in biogenic substances. The increasing role of groundwater is reflected in decreasing trophic character.

- The disappearance of the lake took place probably at the close of the Atlantic period; however, we cannot give the exact date.

- The top layer of sediments constitutes a record of human activity during the most recent times, especially the 20th century. This is reflected in the strong decomposition of peat mass due to drainage and river channel straightening in the 20th century, and in the elevated concentration of phosphorus and heavy metals.

- The results of our study highlight the importance of spatial analysis in environmental reconstructions based on sediment borehole. Analysis of boreholes taken from several points allows us to capture the spatial variability of the processes and their intensity occurring in palaeolakes. Such an approach is particularly important in studies of palaeo-oxbow lakes.

Acknowledgements. The studies were supported by the statutory of the Institute of Geography and Regional Studies, Pomeranian University in Słupsk, project no. 13/1/15. We would like to express our special appreciation to Prof. K. Szeroczyńska (Polish Academy of Sciences, Warsaw) and the anonymous reviewer who helped to improve our manuscript.

\section{REFERENCES}

Aarnes, I., Kühl, N., Birks, H.H., 2012. Quantitative climate reconstruction from late-glacial and early Holocene plant macrofossils in western Norway using the probability density function approach. Review of Palaeobotany and Palynology, 170: 27-39.

Abraham, J., 1998. Spatial distribution of major and trace elements in shallow reservoir sediments: an example from Lake Waco, Texas. Environmental Geology, 36: 349-363.

Adamska, A., Mikulski, J.S., 1969. Cladocera remains in the superficial sediments of lakes as a typologic indicator. Zeszyty Naukowe UMK 25, Prace Stacji Limnologicznej w Iławie, 5: 41-48.

Alhonen, P., 1970. The paleolimnology of four lakes in south-western Finland. Annales Academiae Scientiarum Fennicae, Series A III, 105: 1-39.
Alten, F., Wndrowsky, B., Knippenberg, A., 1935. Beitrag zur Humusbeimmung. Ergebnisse der Agrikulturchemie, 4: 61-69.

Aptroot, A., van Geel, B., 2006. Fungi of the colon of the Yukagir Mammoth and from stratigraphically related permafrost samples. Review of Palaeobotany and Palynology, 141: 225-230.

Boyle, J., 2001. Redox remobilization and the heavy metal record in lake sediments: a modelling approach. Journal of Paleolimnology, 26: 423-431.

Borówka, R.K., 2007. Geochemiczne badania osadów jeziornych strefy umiarkowanej (in Polish). Studia Limnologica et Telmatologica, 1: 33-42.

Bos, J.A.A., Bohncke, S.J.P., Janssen, C.R., 2007. Lake-level fluctuations and small-scale vegetation patterns during the Late Glacial in the Netherlands. Journal of Paleolimnology, 35: 211-238. 
Bronk Ramsey, C., 2013. OxCal. Version 4.2.3. Oxford Radiocarbon Accelerator Unit Research Laboratory for Archaeology, Oxford.

Dembowska, E., Napiórkowski, P., 2012. Why do we have to protect old river beds? (in Polish with English summary). Kosmos, 61: 341-349.

Duigan, C.A., 1992. The ecology and distribution of the littoral freshwater Chydoridae (Branchiopoda, Anomopoda) of Ireland with taxonomic comments on some species. Hydrobiologia, 241: $1-70$.

Dybova-Jachowicz, S., Sadowska, A., 2003. Palinologia (in Polish). Wydawnictwo Instytutu Botaniki PAN, Kraków.

Enders, S.K., Pagani, M., 2008. Compound-specific stable isotopes of organic compounds from lake sediments track recent environmental changes in an alpine ecosystem, Rocky Mountain National Park, Colorado. Limnology and Oceanography, $\mathbf{5 3}$ $1468-1478$.

Faegri, K., Iversen, J., 1989. Textbook of Pollen Analysis. J. Wiley and Sons Ltd., Chichester-Singapore.

Finsinger, W., Tinner, W., van der Knaap, W.O., Ammann, B. 2006. The expansion of hazel (Corylus avellana L.) in the southern Alps: a key for understanding its early Holocene history in Europe? Quaternary Science Reviews, 25: 612-631.

Flössner, D., 1964. Zur Cladoceranfauna des Stechlin-Gebietes. II. Ökologische Untersuchungen über die litoralen Arten. Limnologica, 2: 35-103.

Flössner, D., 2000. Die Haplopoda und Cladocera (ohne Bosminidae) Mitteleuropas. Backhuys Publishers, Leiden.

Frey, D.G., 1958. The Late Glacial cladoceran fauna of a small lake. Archiv für Hydrobiologie, 54: 209-275.

Frey, D.G., 1962. Cladocera from the Eemian Interglacial of Denmark. Journal of Palaeontology, 36: 1133-1154.

Frey, D.G., 1986. Cladocera analysis. In: Handbook of Holocene Palaeoecology and Palaeohydrology (ed. B.E. Berglund) 667-692. Wiley, Chichester UK

Galbarczyk-Gąsiorowska, L., Gąsiorowski, M., Szeroczyńska K., 2009. Reconstruction of human influence during the last two centuries on two small oxbow lakes near Warsaw (Poland). Hydrobiologia, 631: 173-183.

Giesecke, T., Bennett, K.D., Birks, H.J.B., Bjune, A.E., Bozilova, E., Feurdean, A., Finsinger, W., Froyd, C., Pokorný, P., Rösch, M., Seppä, H., Tonkov, S., Valsecchi, V., Wolters, S. 2011. The pace of Holocene vegetation change - testing for synchronous developments. Quaternary Science Reviews, 30: 2805-2814.

Goulden, C.E., 1964. The history of the cladoceran fauna of Esthwaite Water (England) and its limnological significance. Archiv für Hydrobiologie, 60: 1-53.

Haggard, B.E., Moore, P.A., DeLaune, P.B., 2005. Phosphorus flux from bottom sediments in Lake Eucha, Oklahoma. Journal of Environmental Quality, 34: 724-728.

Hamilton-Taylor, J., 1979. Enrichments of zinc, lead and cooper in recent sediments of Windmere, England. Environmental Science and Technology, 13: 693-697.

Hammer, O., Harper, D.A.T., Ryan, P.D., 2001. PAST: palinological statistics software package for education and data analysis. Paleontologica Electronica, 4.

Herczeg, A.L., 1988. Early diagenesis of organic matter in lake sediments: a stable carbon isotope study of pore waters. Chemical Geology, 72: 199-209.

Hofmann, W., 1986. Developmental history of the Grosser Plöner See and the Schöhsee (north Germany): cladoceran analysis, with special reference to eutrophication. Archiv für Hydrobiologie. Suppl., 74: 259-287.

Hofmann, W., 2000. Response of the chydorid faunas to rapid climatic changes in four alpine lakes at different altitudes. Palaeogeography, Palaeoclimatology, Palaeoecology, 159: 281-292.

Isarin, R.F.B., Bohncke, S.J.P., 1999. Mean July temperatures during the Younger Dryas in Northwestern and Central Europe as inferred from climate indicator plant species. Quaternary Research, 51: 158-173.
Jankovská, V., Komárek, J., 2001. Indicative value of Pediastrum and other coccal green algae in palaeoecology. Folia Geobotanica, 35: 59-82

Jin, Z., Li, F., Cao, J., Wang, S., Yu, J., 2006. Geochemistry of Daihai lake sediments, inner Mongolia, north China: implication for provenance, sedimentary sorting, and catchment weathering. Geomorphology, 80: 147-163.

Kajak, Z., 2001. Hydrobiologia - limnologia. Ekosystemy wód śródlądowych (in Polish). PWN, Warszawa.

Kalinowska, K., 1961. Disappearance of post-glacial lakes on the territory of Poland (in Polish with English summary). Przegląd Geograficzny, 33: 511-518.

Karasiewicz, M.T., Hulisz, P., Noryśkiewicz, A.M., Krześlak, I., Świtoniak, M., 2014. The record of hydroclimatic changes in the sediments of a kettle-hole in a young glacial landscape (north-central Poland). Quaternary International, 328: 264-276.

Kondracki, J., 2000. Geografia regionalna Polski (in Polish). PWN Warszawa.

Korhola, A., 1990. Paleolimnology and hydroseral development of the Kotasuo Bog, Southern Finland, with special reference to the Cladocera. Annales Academiae Scientiarum Fennicae, 155: $5-40$

Korhola, A., Rautio, M., 2001. Cladocera and other branchiopod crustaceans. In: Tracking Environmental Change Using Lake Sediments, 4 (eds. J.P. Smol, H.J.B. Birks and W.M. Last): 5-41. Zoological indicators, Kluwer Academic Publishers.

Kotarbiński, K., 2003. Objaśnienia do Szczegółowej mapy geologicznej Polski 1:50 000, arkusz Bieżuń (in Polish). Państwowy Instytut Geologiczny, Warszawa.

Krause-Dellin, D., Steinberg, C., 1986. Cladoceran remains as indicators of lake acidification. Hydrobiologia, 143: 129-134.

Kuhry, P., 1997. The palaeoecology of a treed bog in western boreal Canada: a study based on microfossils, macrofossils and physicochemical properties. Review of Palaeobotany and Palynology, 96: 183-224.

Lampert, W., Sommer, U.S., 2001. Limnoecology. Oxford University Press.

Last, W.M., Smol, J.P., 2001. Tracking Environmental Change Using Lake Sediments. Kluwer Academic Publishers, Dordrecht, The Netherlands.

Latałowa, M., 1982. Postglacial vegetation changes in the eastern coastal zone of Poland. Acta Palaeobotanica, 22: 179-249.

Latałowa, M., Tobolski, K., 1989. Type region P-u: Baltic shore. Acta Palaeobotanica, 29: 109-114.

Magny, M., Bégeot, C., 2004. Hydrological changes in the European midlatitudes associated with freshwater outbursts from Lake Agassiz during the Younger Dryas event and the early Holocene. Quaternary Research, 61: 181-192.

Marszelewski, W., Ptak, M., Skowron, R., 2011. Anthropogenic and natural conditionings of disappearing lakes in the Wielkopolska-Kujawy Lake District (in Polish with English summary). Roczniki Gleboznawcze, 62: 283-294.

Martinova, M.V., 1993. Nitrogen and phosphor compounds in bottom sediments: mechanisms of accumulation, transformation and release. Hydrobiologia, 252: 1-22.

Meyers, P.A., Lallier-Vergès, E., 1999. Lacustrine sedimentary organic matter records of late Quaternary paleoclimates. Journal of Paleolimnology, 21: 345-372.

Milecka, K., Szeroczyńska, K., 2005. Changes in macrophytic flora and planktonic organisms in Lake Ostrowite, Poland, as a response to climatic and trophic fluctuations. The Holocene, 15: 74-84.

Mirosław-Grabowska, J., Niska, M., 2005. Isotopic and Cladocera records of climate changes of Early Eemian at Besiekierz (Central Poland). Geological Quarterly, 49 (1): 67-74.

Mirosław-Grabowska, J., Zawisza, E., 2014. Late Glacial-early Holocene environmental changes in Charzykowskie Lake (northern Poland) based on oxygen and carbon isotopes and Cladocera data. Quaternary International, 328: 156-166.

Mirosław-Grabowska, J., Niska, M., Sienkiewicz, E., 2009. Evolution of the palaeolake at Ruszkówek (central Poland) during 
the Eemian Interglacial based on isotope, cladoceran and diatom data. Journal of Paleolimnology, 42: 467-481.

Nalepka, D., Walanus, A., 2003. Data processing in pollen analysis. Acta Palaeobotanica, 43: 125-134.

Niska, M., 2013. Ewolucja stawu młyńskiego w dolinie Jarosławianki w świetle analizy kopalnych szczątków Cladocera (Crustacea) (in Polish). In: Środowisko glebotwórcze i gleby dolin rzecznych (eds. J. Jonczak and W. Florek): 103-112. Wydawnictwo Naukowe Bogucki, Poznań.

Page, A.L., ed., 1982. Methods of Soil Analysis. Part 2. Chemical and Microbiological Properties.

Pawłowski, D., 2012. Younger Dryas Cladocera assemblages from two valley mires in central Poland and their potential significance for climate reconstructions. Geologos, 18: 237-249.

Pawłowski, D., Płóciennik, M., Brooks, S.J., Luoto, T.P., Milecka K., Nevalainen, L., Peyron, O., Self, A., Zieliński, T., 2015a. A multi-proxy study of Younger Dryas and Early Holocene climatic conditions from the Grabia River palaeo-oxbow lake (central Poland). Palaeogeography, Palaeoclimatology, Palaeoecology, 438: $34-50$

Pawłowski, D., Kowalewski, G., Milecka, K., Płóciennik, M., Woszczyk, M., Zieliński, T., Okupny, D., Włodarski, W., Forysiak, J., 2015b. A reconstruction of the paleohydrological conditions of a flood-plain: a multi-proxy study from the Grabia River valley mire, central Poland. Boreas, 44: 543-562.

Poulsen, E., 1944. Entomostraca from a late-glacial lacustrine deposit at Næstved, Denmark. Meddelelser fra Dansk Geologisk Forening, 10: 405-416.

Ralska-Jasiewiczowa, M., Tobolski, K., Nalepka, D., 2004. Typha latifolia L. - Bulrush, cat-tail. In: Late Glacial and Holocene history of vegetation in Poland based on isopollen maps (eds. M. Ralska-Jasiewiczowa, M. Latałowa, K. Wasylikowa, K. Tobolski, E. Madeyska, H.E. Jr. Wright and Ch. Turner): 359-369. W. Szafer Institute of Botany, Polish Academy of Sciences, Kraków.

Reimer, P.J., Bard, E., Bayliss, A., Beck, J.W., Blackwell, P.G., Bronk Ramsey, C., Grootes, P.M., Guilderson, T.P., Haflidason, H., Hajdas, I., Hatté, C., Heaton, T.J., Hoffmann, D.L., Hogg, A.G., Hughen, K.A., Kaiser, F., Kromer, B., Manning, S.W., Niu, M., Reimer, R.W., Richards, D.A., Scott, E.M., Southon, J.R., Staff, R.A., Turney, C.S.M., van der Plich, J., 2013. IntCal13 and marine 13 radiocarbon age calibration curves 0-50,000 years cal BP. Radiocarbon, 55: 1869-1887.

Rose, N.L., Boyle, J.F., Du, Y., Yi, C., Dai, X., Appleby, P.G. Bennion, H., Cai, S., Yu, L., 2004. Sedimentary evidence for changes in the pollution status of Taihu in the Jiangsu region of eastern China. Journal of Paleolimnology, 32: 41-51.

Rybak, J.I., Błędzki, L.A., 2010. Słodkowodne skorupiaki planktonowe (in Polish). Wydawnictwa Uniwersytetu Warszawskiego, Warszawa.

Sarmaja-Korjonen, K., 2003. Chydorid ephippia as indicators of environmental change - biostratigraphical evidence from two lakes in southern Finland. The Holocene, 13: 691-700.

Schmidt, R., Roth, M., Tessadri, R., Weckstrom, K., 2008. Disentangling late-Holocene climate and land use impacts on an Aus- trian alpine lake using seasonal temperature anomalies, ice-cover, sedimentology, and pollen tracers. Journal of Paleolimnology, 40: 453-469.

Szeroczyńska, K., 1985. Cladocera as ecological indicator in late Quaternary lacustrine sediments, Northern Poland (in Polish with English summary). Acta Palaeontologica Polonica, 30: 3-69.

Szeroczyńska, K., 1998. Palaeolimnological investigations in Poland based on Cladocera (Crustacea). Palaeogeography, Palaeoclimatology, Palaeoecology, 140: 335-345.

Szeroczyńska, K., 2006. The significance of subfossil Cladocera in stratigraphy of Late Glacial and Holocene. Studia Quaternaria, 23: $37-45$.

Szeroczyńska, K., Sarmaja-Korjonen, K., 2007. Atlas of Subfossil Cladocera from Central and Northern Europe. Towarzystwo Przyjaciół Dolnej Wisły, Świecie.

Szeroczyńska, K., Zawisza, E., 2007. Paleolimnologia - historia rozwoju jezior w Polsce w świetle badań fauny wioślarek (in Polish). Studia Limnologica et Telmatologica, 1: 51-60.

Van Geel, B., 2001. Non-pollen palynomorphs. In: Tracking Environmental Change Using Lake Sediments, 3: Terrestrial, Algal, and Siliceous indicators (eds. J.P. Smol, H.J.B. Birks and W.M. Last): 99-111. Kluwer Academic Publishers, Dordrecht, The Netherlands.

Van Geel, B., Coope, G.R., van der Hammen, T., 1989. Palaeoecology and stratigraphy of the Lateglacial type section at Usselo (The Netherlands). Review of Palaeobotany and Palynology, 60: 25-129.

Wilson, T.A., Norton, S.A., Lake, B.A., Amirbahman, A., 2008. Sediment geochemistry of $\mathrm{Al}, \mathrm{Fe}$, and $\mathrm{P}$ for two historically acidic, oligotrophic Maine lakes. Science of the Total Environment, 404: 269-275.

Whiteside, M.C., 1970. Danish chydorid Cladocera: modern ecology and borehole studies. Ecological Monographs, 40: 79-118 .

Whiteside, M.C., Swindoll, M.R., 1988. Guidelines and limitations to cladoceran paleoecological interpretations. Palaeogeography, Palaeoclimatology, Palaeoecology, 62: 405-412.

Wojciechowski, A., 1987. Geochemical profile of deposits in lake Gardno (in Polish with English summary). Badania Fizjograficzne nad Polską Zachodnia, ser. A. Geografia Fizyczna, 37: 191-211.

Wojciechowski, A., 2000. Zmiany paleohydrologiczne w środkowej Wielkopolsce w ciagu ostatnich 12000 lat w świetle badań osadów jeziornych rynny kórnicko-zaniemyskiej (in Polish). Wydawnictwo Naukowe UAM, seria Geografia, 63.

Zawiska, I., Słowiński, M., Correa-Metrio, A., Obremska, M., Luoto, T., Nevalainen, L., Woszczyk, M., Milecka, K., 2015. The response of a shallow lake and its catchment to Late Glacial climate changes - a case study from eastern Poland. Catena, 126: $1-10$. 